\title{
Peningkatan Kualitas Pelayanan Publik Melalui Implementasi E- Government di Bali
}

\author{
Made Dian Putri Agustina ${ }^{1^{*}}$ \\ ${ }^{1}$ Universitas Hindu Indonesia, Denpasar - Indonesia
}

\author{
A R T I C L E I N F O \\ Article history: \\ Received Decemeber, 10 \\ 2021 \\ Received in revised form \\ December, 212021 \\ Accepted December, 24 \\ 2021 \\ Available online December, \\ 252021

\section{Kata Kunci:} \\ E-government, kualitas \\ pelayanan, pelayanan \\ publik, transformasi digital. \\ Keywords: \\ E-government, digital \\ transformation, public \\ service, service quality.
}

\begin{abstract}
A B S T R A K
E-Government merupakan salah satu layanan publik teknologi informasi yang disediakan oleh pemerintah untuk meningkatkan kinerja, efisiensi, akuntabilitas, dan kepercayaan publik. Namun, masih banyak pengaduan masyarakat tentang dugaan kecurangan administrasi dalam pelayanan publik. Tujuan dari penelitian ini adalah untuk mengetahui keterkaitan antara transformasi digital melalui pengenalan e-government dengan peningkatan kualitas pelayanan publik di Bali serta manakah dari dua faktor tersebut yang mempengaruhi kualitas pelayanan publik melalui pengenalan e-Government di Bali. Studi ini dilakukan pada masyarakat di Provinsi Bali yang sudah pernah menggunakan layanan publik online. Data dikumpulkan melalui instrumen kuesioner online dengan sampel sebanyak 70 responden. Teknik analisis menggunakan analisis PLS. Hasil analisis menunjukkan bahwa peran masyarakat, ICT dan E-Government berpengaruh signifikan terhadap kualitas pelayanan publik di Provinsi Bali. E-Goverment memiliki peran penting dalam meningkatkan kualitas layanan public secara optimal di Provinsi Bali.
\end{abstract}

\section{A B S T R A C T}

E-Government is one of the information technology public services provided by the government to improve performance, efficiency, accountability, and public trust. However, there are still many public complaints about alleged administrative fraud in public services. The purpose of this study is to determine the relationship between digital transformation through the introduction of e-government and improving the quality of public services in Bali and which of these two factors affect the quality of public services through the introduction of e-government in Bali. This study was conducted on people in Bali Province who have used online public services. Data were collected through an online questionnaire instrument with a sample of 70 respondents. The analysis technique uses PLS analysis. The results of the analysis show that the role of the community, ICT and E-Government have a significant effect on the quality of public services in the Province of Bali. E-Government has an important role in improving the quality of public services optimally in the Province of Bali.

\footnotetext{
* Corresponding author.

E-mail : dianagustina@unhi.ac.id (Made Dian Putri Agustina)
} 


\section{Pendahuluan}

Peraturan Presiden Republik Indonesia 95 Tahun 2018 tentang Sistem Elektronik Pemerintah memastikan bahwa Elektronik Pemerintah mencapai tata kelola pemerintahan yang bersih, efektif, transparan, akuntabel, serta pelayanan publik yang berkualitas dan terpercaya. Sistem e-government (selanjutnya disingkat SPBE) adalah instansi pemerintah yang menggunakan teknologi informasi dan komunikasi untuk memberikan pelayanan kepada pengguna SPBE. Untuk mencapai tujuan tersebut, pemerintah menggunakan teknologi informasi dan komunikasi (TIK). Ia berperan penting dalam mempercepat pencapaian tujuan pemerintah di sektor publik dan berkontribusi terhadap pertumbuhan ekonomi daerah (Bertucci, 2008).

Berdasarkan data laporan tahunan Lembaga Ombudsman RI periode tahun 2019 menerima laporan/ pengaduan masyarakat atas dugaan maladministrasi dalam pelayanan publik sebanyak 7.903 laporan. Berdasarkan sebaran laporan/laporan masyarakat Bali sebanyak 129 laporan seperti ditunjukkan pada Gambar 1.

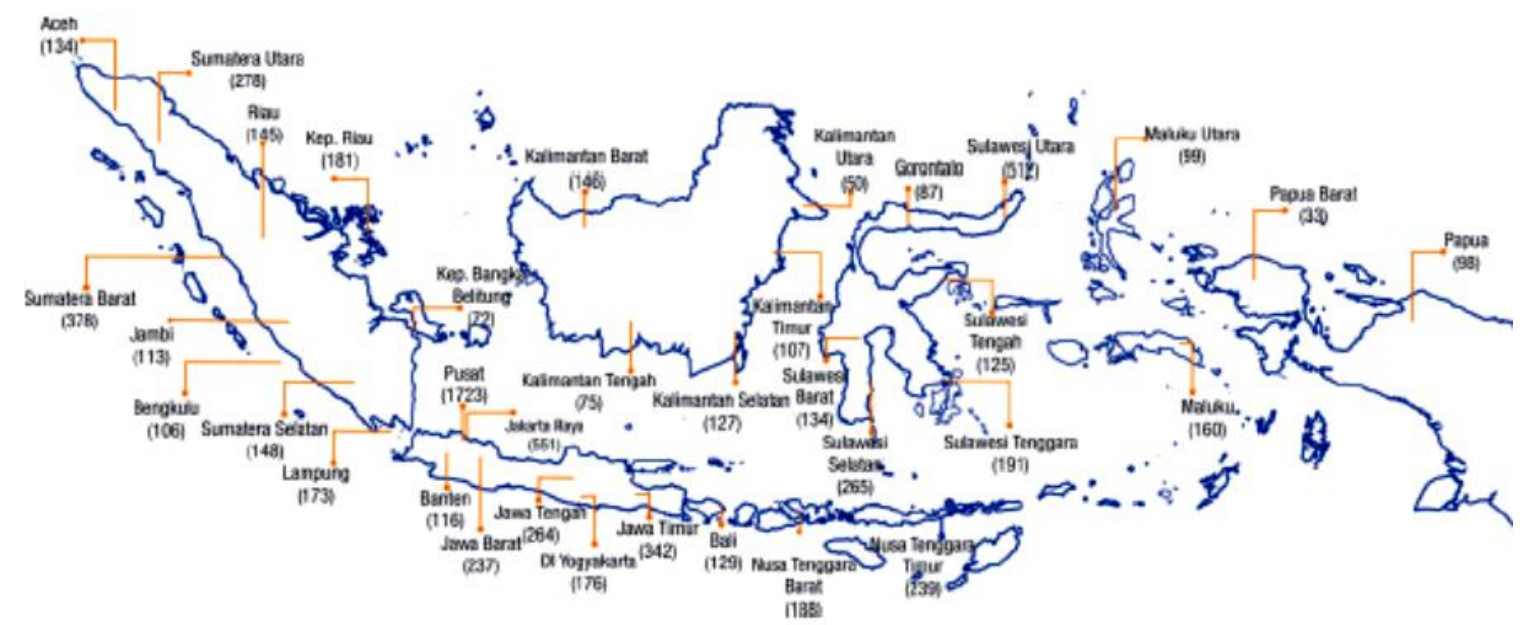

Gambar 1. Sebaran laporan/Pengaduan masyarakat.

Sumber: Laporan tahunan Obudsman RI, (2019).

Berdasarkan data yang digunakan untuk mengklasifikasikan dugaan penyelewengan administrasi, tiga jenis keterlambatan yang paling umum adalah keterlambatan lama 33,62\%, penyimpangan prosedur 28,97\%, dan non-pelayanan 17,70\%. Gambar 2 menunjukkan data dugaan penyelewengan. Berdasarkan data otoritas yang dilaporkan, tiga otoritas yang paling sering dilaporkan adalah $41,62 \%$ untuk pemerintah daerah, 11,22\% untuk lembaga pemerintah/kementerian, dan 10,25\% untuk kepolisian. Hal ini perlu segera dibenahi agar ke depan kepercayaan publik pemerintah terhadap penyelenggaraan pelayanan publik yang berkualitas akan segera terwujud. Teknologi informasi memegang peranan penting, terutama dalam transformasi digital pemerintah pusat dan daerah di Bali.
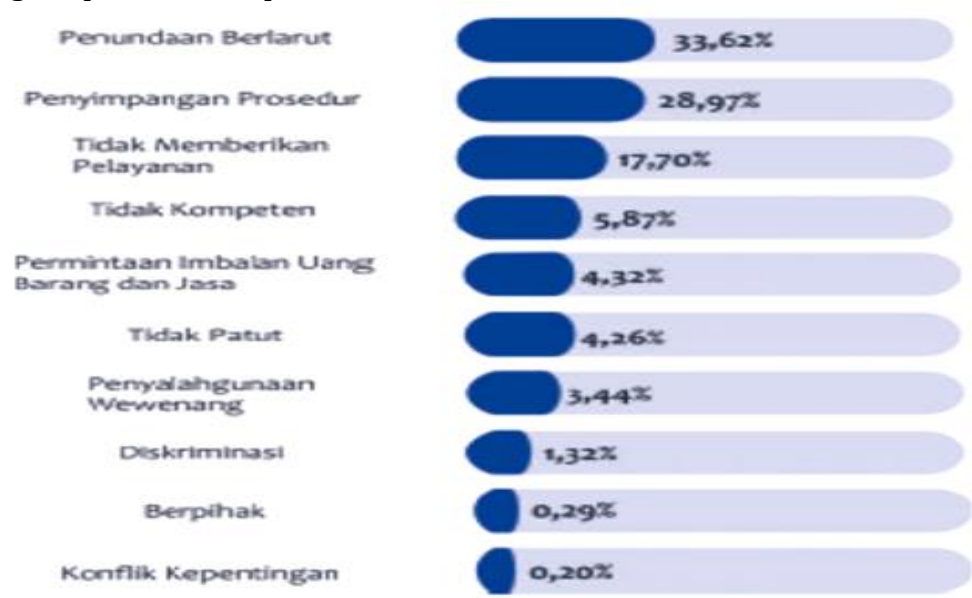

Gambar 2. Dugaan Maladministrasi.

Sumber: Laporan tahunan Obudsman RI, (2019) 
Saat ini, teknologi informasi (TI) tidak hanya terkait erat dengan teknologi informasi dan sistem informasi, tetapi juga membuat langkah besar di berbagai bidang seperti kebijakan pemerintah dan ekonomi (Susanto \& Bahaweres, 2013). E-Governance (e-Government) adalah instansi pemerintah yang menggunakan teknologi informasi dan komunikasi untuk melayani pengguna e-government. H. Masyarakat untuk menyediakan. Untuk mendorong peningkatan kualitas pelayanan publik, diperlukan perubahan paradigma pemerintah untuk mengoptimalkan e-government.

Dalam konteks pelayanan publik, pelayanan publik dikatakan mengutamakan kepentingan publik, memajukan hubungan masyarakat, mengurangi waktu yang dibutuhkan untuk mempublikasikan, dan menyenangkan publik. Moenir (1992) menyatakan bahwa pelayanan publik dilakukan oleh individu atau kelompok orang berdasarkan faktor-faktor kunci untuk melayani kepentingan orang lain sesuai dengan haknya melalui sistem, prosedur dan metode tertentu yang menunjukkan bahwa itu adalah suatu kegiatan. Pelayanan publik didefinisikan sebagai pelayanan (melayani) kebutuhan individu atau komunitas yang tertarik pada suatu organisasi, mengikuti aturan dan prosedur dasar yang ditetapkan. (Kurniawan dalam Sinambela. LP, 2008).

Menurut United Nations (2020), E-Government memiliki peran menyediakan masyarakat dengan layanan dasar seperti pendidikan, kesehatan, keuangan dan perawatan sosial, dan dapat menjadi indikator pembangunan. Untuk meningkatkan sektor publik, pemerintah perlu meningkatkan kinerja, efisiensi, akuntabilitas, kepercayaan dan lebih fokus pada penyediaan layanan yang lebih baik. E-government sering meningkatkan kualitas layanan dengan (1) membuat informasi dan layanan pemerintah dapat diakses oleh masyarakat umum, dan (2) meningkatkan kecepatan, kelengkapan, dan proses informasi yang lebih efisien. Ini digambarkan sebagai operasi TI yang bertujuan membuat itu terjadi. Menyediakan platform dan kesempatan bagi masyarakat untuk berpartisipasi sebagai bentuk proses demokrasi.

Karena masyarakat mungkin menuntut kualitas layanan yang lebih baik, penting bagi pemerintah untuk terus menilai dan mengidentifikasi masalah guna meningkatkan kualitas layanan untuk memenuhi kebutuhan masyarakat (Nguyen, 2014). .. Masalah terkait adalah sejumlah besar orang yang, meskipun lembaga negara, tidak sepenuhnya mendapat manfaat dari layanan e-government. Hal ini mungkin disebabkan oleh rendahnya kualitas layanan yang diberikan atau ketidakpercayaan publik terhadap layanan yang diberikan oleh pemerintah. Untuk memberikan layanan yang efisien dan hemat biaya serta menjaga kepercayaan publik, pemerintah perlu memahami dan memperhitungkan pandangan masyarakat sebagai penilaian kualitas layanan e-government itu sendiri (Zaidi, 2004).

Berdasarkan paparan latar belakang di atas, kami akan melakukan analisis untuk meningkatkan kualitas pelayanan publik dengan memperkenalkan e-government di Bali. Analisis e-government dari perspektif government-to-citizens (G2C) dan government-to-business (G2B). Pertanyaan kunci yang dibahas dalam survei ini adalah: Pertama, adakah keterkaitan antara transformasi digital pengenalan egovernment dengan peningkatan kualitas pelayanan publik di Bali? Manakah dari dua faktor tersebut yang mempengaruhi kualitas pelayanan publik melalui pengenalan e-Government di Bali? Kajian menunjukkan masyarakat sebagai pengguna utama layanan publik pemerintah dan pemerintah sebagai penyedia layanan. Proses evaluasi dilihat dari sisi pengguna layanan (masyarakat) dan penyedia layanan (pemerintah).

\section{Metode}

Survei ini menggunakan survei kuantitatif. Proses pengumpulan data menggunakan pendekatan perseptual untuk memudahkan pengukuran. Pengumpulan data dilakukan dengan menggunakan kuesioner yang telah diuji validitas dan reliabilitasnya. Selanjutnya hasil data kuisioner diperiksa dengan analisis multivariat menggunakan metode analisis PLS. Survei dilakukan terhadap individu yang menggunakan layanan publik online di Bali. Karena populasi penelitian ini adalah masyarakat yang pernah menggunakan layanan publik online dan jumlah populasinya tidak diketahui dalam penelitian ini, maka penentuan ukuran sampel didasarkan pada jumlah indikator survei. Jumlah indikator yang dibutuhkan minimal lima kali jumlah variabel indikator (Ferdinand, 2014). Karena survei ini menggunakan 14 indikator, maka survei ini menggunakan sampel sebanyak 70 responden. Metode pengambilan sampel yang digunakan dalam survei ini adalah random sampling, dan sampel ditentukan secara acak pada setiap titik waktu, dengan mempertimbangkan bahwa responden telah menggunakan layanan publik online.

\section{Hasil dan pembahasan}

Evaluasi model kuadrat terkecil parsial (PLS) terdiri dari dua tahap yaitu evaluasi model pengukuran (model eksternal) dan evaluasi model struktural (model internal). Langkah pertama adalah model pengukuran, yaitu model yang menunjukkan hubungan antara variabel laten (konstruksi) dengan indikatornya. Model pengukuran diuji dalam tiga langkah pengujian. (1) Uji validitas konvergen. (2) 
Validitas identifikasi. (3) Verifikasi reliabilitas (reliabilitas validitas). Data valid dan reliabel berdasarkan tiga uji model pengukuran yang dilakukan. Sama seperti Tabel 1 dan Tabel 2.

Tabel 1. nilai average variance extracted (ave) terhadap konstruk model

\begin{tabular}{lcc}
\hline \multicolumn{1}{c}{ Variabel Konstruk } & Average Variance Extracted $(A V E)$ & Keterangan \\
\hline Peran Masyarakat $\left(\mathrm{X}_{1}\right)$ & 0,771 & Valid \\
ICT $\left(\mathrm{X}_{2}\right)$ & 0,847 & Valid \\
E-Goverment $\left(\mathrm{X}_{3}\right)$ & 0,785 & Valid \\
Kualitas Layana Public $(\mathrm{Y})$ & 0,809 & Valid \\
\hline
\end{tabular}

Berdasarkan Tabel 1, hasil uji nilai mean variance extraction (AVE) untuk konfigurasi menunjukkan bahwa semua variabel dalam model dianggap valid. Diurutkan dari peran masyarakat (X1). Nilai ICT (X2); EGoverment (X3) dan Public Service Quality (Y) AVE adalah 0,771. 0,847; 0,785; dan 0,809.

Konfigurasi reliabilitas merepresentasikan konsistensi suatu konsep atau variabel terukur (S. Schindler, 2006). Reliabilitas dapat diukur dengan menguji reliabilitas yang dikombinasikan dengan faktor alfa Cronbach. Alpa Clonbach mengukur batas bawah skor reliabilitas konstitutif, dan reliabilitas komposit adalah reliabilitas konstitutif (Chin, 1995; Gopal, Salisbury et al, 1997) dan (Newsted, 2002) oleh (Abdillah). \& Jogiyanto. , Nilai sebenarnya dari 2015) Keandalan gabungan dan nilai alfa Cronbach lebih besar dari 0,7. Uji alpha statistik Clonback digunakan untuk memeriksa reliabilitas dengan memeriksa konsistensi internal dari alat penelitian yang digunakan. Jika nilai Cronbach's alpha dalam ilmu-ilmu sosial lebih besar atau sama dengan 0,60 (Nunnally, Bernstein, 1994) dan AVE lebih besar dari 0,5, alat penelitian tersebut dinyatakan reliabel. Ini masih dapat diterima untuk ekspor penelitian (Hair et al, 2010). Berdasarkan hasil pengolahan data yang ditunjukkan pada Tabel 2, koefisien alfa Cronbach termasuk reliabilitas alfa atau majemuk.

Tabel 1. Reliabilitas dan Validitas Konstruk

\begin{tabular}{llll}
\hline \multicolumn{1}{c}{ Variabel Laten } & Cronbach's Alpa & Composite Relibility & Keterangan \\
\hline Peran Masyarakat $\left(\mathrm{X}_{1}\right)$ & 0,851 & 0,910 & Reliable \\
ICT $\left(\mathrm{X}_{2}\right)$ & 0,910 & 0,955 & Reliable \\
E-Goverment $\left(\mathrm{X}_{3}\right)$ & 0,865 & 0,916 & Reliable \\
Kualitas Layana Public $(\mathrm{Y})$ & 0,940 & 0,955 & Reliable \\
\hline
\end{tabular}

Berdasarkan Gambar 3. dapat dilihat bahwa pengaruh langsung Peran masyarakat, ICT dan Egovernment. Nilai path coefficient yang paling besar mempengaruhi adalah E-government dengan nilai coefficint sebesar 0,810. Hal ini menunjukkan bahwa E-government, memiliki peran penting dalam meningkatkan kualitas layanan public secara optimal dan signifikan di Provinsi Bali.

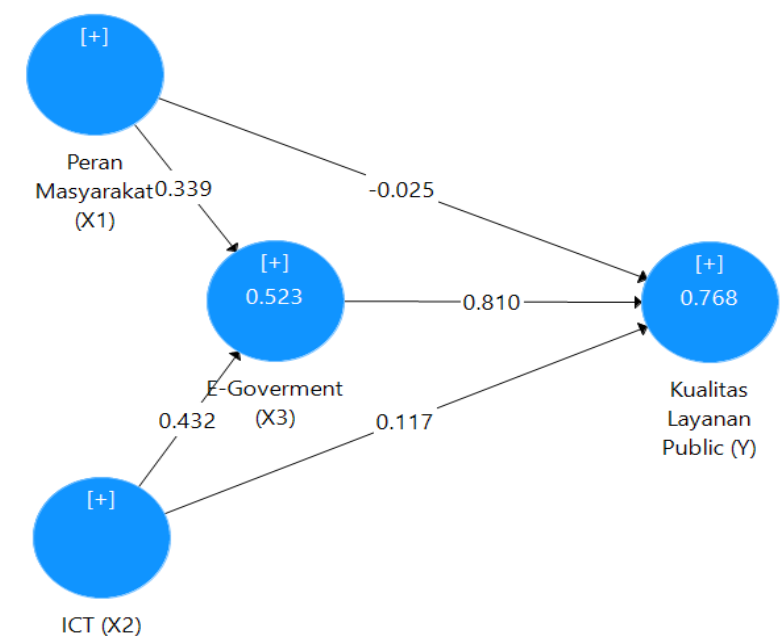

Gambar 3. Path Coefficient, Digital Transformation: Improving the Quality of Public Services Through the Implementation of E-Government in Bali 
Setelah mode pengukuran dievaluasi, tahap kedua, evaluasi model struktural (model internal), dilanjutkan. Model ini mengevaluasi hubungan antara variabel laten dari model penelitian. Model struktural diukur dengan SEM-PLS dengan mengevaluasi R-Square (R2), Goodness of Inner Fit. Nilai R-Square digunakan untuk menilai perubahan variabel laten ekstrinsik ketika menggambarkan variabel laten intrinsik. Semakin tinggi nilai R-Square, semakin baik model prediksi penelitian. Jika hasil R-square variabel laten intrinsik model struktural melebihi 0,67 menunjukkan bahwa pengaruh variabel ekstrinsik (terpengaruh) terhadap variabel intrinsik (terpengaruh) berada pada kategori baik. Sebaliknya, jika hasilnya 0,33 hingga 0,67 maka tergolong "sedang", dan jika 0,19 hingga 0,33 tergolong "lemah" (Ghozali, 2011). Nilai Q-Square $>0$ menunjukkan model bersifat prediktif, sedangkan nilai Q-Square $<=0$ menunjukkan model tidak prediktif (Solimun, 2002; Ghozali, 2006). Tabel 3 menunjukkan hasil perhitungan R-Square dari model survei. Berdasarkan Tabel 3 dapat dideskripsikan bahwa hasil pengujian model struktur nilai R-Square berada pada kategori sedang, dan nilai Goodness of Fit Inner adalah penting. Seperti Tabel 3.

Tabel 2. Nilai R-Square Variabel Penelitian

\begin{tabular}{llll}
\hline Variabel Laten & R-Square & $\begin{array}{l}\text { R-Square Adjusted } \\
\text { Adjusted Adjusted }\end{array}$ & Keterangan \\
\hline E-Goverment $\left(\mathrm{X}_{2}\right)$ & 0,523 & 0,507 & Moderat, Relevence \\
Kualitas Layana Public (Y) & 0,768 & 0,756 & Baik, Relevance \\
\hline
\end{tabular}

Berikutnya dilakukan analisis pengaruh langsung dengan tujuan untuk menganalisis pengaruh langsung antar konstruk. Besar pengaruh langsung antar konstruk ditunjukkan seperti Tabel 4.

Tabel 3. Path Coefficient Pengaruh Langsung antar Variabel Penelitian

\begin{tabular}{lccccl}
\hline \multicolumn{1}{c}{ Konstruk } & Original & Standard & $T_{\text {Statistic }}$ & $P_{\text {Value }}$ & Keterangan \\
\hline $\mathrm{X}_{1} \rightarrow \mathrm{X}_{3}$ & 0,331 & 0,087 & 3,817 & 0,000 & Signifikan \\
$\mathrm{X}_{2} \rightarrow \mathrm{X}_{3}$ & 0,419 & 0,112 & 3,723 & 0,000 & Signifikan \\
$\mathrm{X}_{1} \rightarrow \mathrm{Y}$ & 0,293 & 0,109 & 2,684 & 0,008 & Signifikan \\
$\mathrm{X}_{2} \rightarrow \mathrm{Y}$ & 0,078 & 0,102 & 0,767 & 0,004 & Signifikan \\
$\mathrm{X}_{3} \rightarrow \mathrm{Y}$ & 0,506 & 0,101 & 5,026 & 0,000 & Signifikan \\
\hline
\end{tabular}

Keterangan:

$\mathrm{X}_{1}$ : Peran Masyarakat

$\mathrm{X}_{2}:$ ICT

$\mathrm{X}_{3}$ : E-Goverment

Y: Kualitas Layanan Publik

Berdasarkan Tabel 4 dapat dijelaskan bahwa secara langsung peran masyarakat dan ICT berpengaruh positif signifikan terhadap E-Government. Peran masyarakat, ICT dan E-Government secara langsung berpengaruh terhadap Kualitas Layanan Publik. Peran masyarakat akan memberikan kepercayaan terhadap jalannya suatu pemerintahan, dengan kata lain partisipasi masyarakat disini dapat dijadikan tolak ukur terhadap legitimasi demokrasi. Dengan peran masyarakat dalam E-Government memberikan peluang bagi pemerintah untuk menentukan arah kebijakannya sesuai dengan keinginan masyarakat dan bagi masyarakat memberikan peluang untuk berperan dalam sistem pemerintah. Penerapan ICT yang baik dapat meningkatkan hubungan antara pemerintah dengan penduduk, bisnis dan kegiatan lainnya. Dengan demikian partisipasi aktif masyarakat, penerapan ICT yang baik dan juga didasarkan oleh E-Government yang transparan, efisien dan aman tentunya dapat meningkatkan kualitas layanan publik seperti yang diinginkan oleh masyarakat.

Selanjutnya pengaruh tidak langsung Peran Masyarakat, ICT terhadap Kualitas Layanan Public melalui E-Goverment, dapat dilihat pada Tabel 5 berikut. 
Tabel 4. Nilai Indirect Effect, Pengaruh Tidak Langsung Antar Variabel Penelitian

\begin{tabular}{lcccccl}
\hline \multicolumn{1}{c}{ Konstruk } & Variabel & Original & Standard & $T_{\text {Statistic }}$ & $P_{\text {value }}$ & Keterangan \\
\hline $\mathrm{X}_{1} \rightarrow \mathrm{Y}$ & $\mathrm{X}_{3}$ & 0,168 & 0,049 & 3,409 & 0,001 & Signifikan \\
$\mathrm{X}_{2} \rightarrow \mathrm{Y}$ & $\mathrm{X}_{3}$ & 0,212 & 0,066 & 3,199 & 0,001 & Signifikan \\
\hline
\end{tabular}

Keterangan:
$\mathrm{X}_{1}$ : Peran Masyarakat
$\mathrm{X}_{2}:$ ICT
$\mathrm{X}_{3}$ : E-Government
Y : Kualitas Layanan Public

Tabel 5 menunjukkan bahwa Peran Masyarakat, ICT memiliki pengaruh tidak langsung terhadap Kualitas Layanan Public Melalui E-Government. Hubungan mediasi pada pengujian ini bersifat positif signifikan. Dengan melihat pengaruh langsung variabel penelitian pada Tabel 4 dan pengaruh tidak langsung pada Tabel 5, maka dapat dinyatakan bahwa peran masyarakat dan ICT berpengaruh signifikat terhadap kualitas layanan publik setelah melalui variabel lain atau dimediasi oleh E-Government. Hal ini menunjukkan peran mediasi E-Government adalah mediasi parsial.

Sebagaimana hasil penelitian tersebut maka E-Government sangatlah penting untuk meningkatkan kualitas layanan publik. Jika E-Government dirancang dengan cara yang terintegrasi maka layanan akan tersedia secara real time sehingga kualitas layanan dapat ditinngkatkan.

\section{Simpulan dan saran}

Dalam kajian ini, dapat ditarik kesimpulan, bahwa E-Government memiliki peran penting dalam meningkatkan kualitas layanan public secara optimal di Provinsi Bali. E-Government diperlukan untuk efisiensi, efektifitas transparansi dan akuntanbilitas pengemplementasi di instansi-instansi pemerintah. Hal tersebut tentunya akan terwujud dengan didukung oleh peran aktif masyarakat dan juga sistem ICT yang baik.

Pemerintah harus memperhatikan masyarakat dalam penyelenggaraan pelayanan publik sehingga tercipta hubungan timbal balik antara penyelenggara pelayanan dan masyarakat sebagai pihak penerima pelayanan. Pemerintah juga harus memaksimalkan dan mengoptimalkan anggaran serta infrastruktur TIK yang tersedia agar dapat memberikan pelayanan yang prima kepada masyarakat. Membangun infrastruktur yang merata dan berkualitas melalui distribusi pembangunan antara Pemerintah Pusat, Daerah, kerjasama, investasi swasta. Kolaborasi membangun kemitraan antar lembaga, pemerintah dengan swasta dalam melakukan penguatan Badan Riset dan Inovasi daerah untuk mengembangkan pemenuhan kebutuhan pendukung transformasi digital. Pemerintah juga harus mengembangkan SDM talenta digital dengan jumlah dan kualitas yang memadai dan berkualitas melalui penyusunan perencanaan kompetensi SDM TIK dan pengembangan perencanaan berbasis digital, pengenalanan sejak dini tentang pemanfaatan TIK kepada anak didik, membangun budaya penerapan TIK pada kehidupan masyarakat dan mengarahkan dunia pendidikan menyediakan SDM unggul TIK.

\section{Daftar Rujukan}

Abdillah, W., \& Jogiyanto. (2015). Partial Least Square (PLS) Alternatif Structural Equation Modeling (SEM) dalam Penelitian Bisnis (ed. 1). Andi.

Alshehri, M., \& Drew, S. (2010). E-government fundamentals. In IADIS international conference ICT, society and human beings.Bertucci, G. (2008). UN e-Government Survey: From e-Government to Connected Governance. In New York: United Nations.

Chin, W. W. (1995). Partial least squares is to LISREL as principal components analysis is to common factor analysis. Technology studies, 2(2), 315-319.Ghozali, I. (2006). Aplikasi Analisis Multivariate Dengan Program SPSS (Cetakan Ke). Badan Penerbit Universitas Diponegoro.

Chin, W. W., Gopal, A., \& Salisbury, W. D. (1997). Advancing the theory of adaptive structuration: The development of a scale to measure faithfulness of appropriation. Information systems research, 8(4), 342-367.

Cooper, D. R., Schindler, P. S., \& Sun, J. (2006). Business research methods (Vol. 9, pp. 1-744). New York: Mcgraw-hill.Solimun. (2002). Structural Equation Modelling (SEM) Lisreldan Amos. FMIPA Universitas Brawijaya.

Ferdinand, A. 2014. Metode Penelitian Manajemen. Semarang: Universitas Diponegoro Press.

Nunnally, Bernstein, I. . (1994). Psychometric Theory (ed. 3). McGraw Hill.

Susanto, A., \& Bahaweres, R. B. (2013, March). Preliminary research on e-government development overview: An assessment on e-Government capabilities in Indonesia. In 2013 International 
Conference of Information and Communication Technology (ICoICT) (pp. 444-447). IEEE.United Nations. (2020). E-Government Survey 2020. Digital Government in the Decade of action for sustainable development. In UN E-Government Knowledgebase.

Zaidi, S. F., Marir, F., \& Siva, S. (2013, February). Assessing e-Government Service \& Trust: Government to Citizen. In The Seventh International Conference on Digital Society (pp. 28-31). 